\title{
Protection against Streptococcus equi infection by monoclonal antibodies against an M-like protein
}

\author{
M. J. Bernadette Jean-François, ${ }^{*} \dagger$ David C. Poskitt, Sarah J. Turnbull, \\ LiSA M. MaCDONALD and DilRUba YaSMEen
}

Commonwealth Serum Laboratories, Research and Development Division, Parkville 3052, Victoria, Australia

(Received 3 July 1990; revised 15 April 1991; accepted 13 May 1991)

\begin{abstract}
We have developed an in vivo passive transfer assay using mice to identify monoclonal antibodies (mAbs) which offer protection against Streptococcus equi infection. The assay was developed using serum antibodies collected from horses convalescing from strangles. In this study, we show that a preparation of $M$-like protein, acidextracted from $S$. equi, affords $80 \%$ protection to mice immunized with it. A number of mouse mAbs directed against a preparation of M-like protein were then assessed for their ability to passively protect mice against challenge with a lethal dose of the bacteria. Two mAbs, $1 D 10$ and $2 \mathrm{A6}$, were shown to be highly protective. It was also demonstrated, by means of a competitive enzyme immunoassay, that these mAbs recognized different epitopes in the preparation. Examination of a dose-response curve for mAbs $1 D 10$ and $2 \mathrm{A6}$ revealed that optimal levels of protection were achieved using $1 \mathrm{mg}$ of either $1 \mathrm{D10}$ or $2 \mathrm{A6}$, or $0.5 \mathrm{mg} 1 \mathrm{D10}$ and $0.5 \mathrm{mg} 2 \mathrm{A6}$ given together. Immunological reactivity of these $\mathrm{mAbs}$ with a preparation of $\mathrm{M}$-like protein showed that the antigens they recognized were comparable in size to some of the antigens recognized by convalescent horse serum antibodies. The role of immunoglobulin isotype in conferring protection is discussed.
\end{abstract}

\section{Introduction}

Streptococcus equi (a group C streptococcus) causes strangles, a contagious disease of the upper respiratory tract in horses characterized in the initial stages by nasal discharge and fever, and eventually by swelling of the regional lymph nodes due to abscess formation. In severe cases, the infection may become disseminated with internal and external abscess formation and may ultimately result in death [Commonwealth Serum Laboratories (CSL) Veterinary Handbook, 1979]. Mounting evidence in the literature indicates that immunity to $S$. equi is local rather than systemic and that it is mediated by mucosal antibodies (Srivastava $\&$ Barnum, 1983, 1985; Timoney \& Eggers, 1985; Timoney \& Galan, 1985; Galan \& Timoney, 1985). The importance of local immunity in conferring protection against group A streptococcal infections is also well documented (Bessen

$\dagger$ Present address: Department of Medicine, University of Melbourne, St Vincents Hospital, Fitzroy 3065, Victoria, Australia.

Abbreviations: ABTS, 2,2'-azino-bis(3-ethylbenzthiazoline-6-sulphonate); CMI, cumulative mortality index; CM-cellulose, carboxymethylcellulose; CSL, Commonwealth Serum Laboratories; EIA, enzyme immunoassay; FCA, Freund's complete adjuvant; FIA, Freund's incomplete adjuvant; HAE, hot-acid extract; HRP, horseradish peroxidase; i.p., intraperitoneally; $\mathrm{mAb}$, monoclonal antibody.
\& Fischetti, 1985a,b). Virulence in group A streptococci is mainly associated with the presence of M-protein, a trypsin-labile component with an $\alpha$-helical coil configuration which spans the bacterial capsule and cell wall (Fox, 1974; Phillips et al., 1981). The M-protein renders the bacterium resistant to non-immune phagocytosis (Bisno, 1979; Peterson et al., 1979). The existence of an M-like protein has also been demonstrated in $S$. equi (Woolcock, 1974). However, the M-like protein has not been conclusively shown to be the major virulence factor of this species, although bacterial extracts containing it confer immunity (Woolcock, 1974; Timoney \& Galan, 1985).

Although only one antigenic type of $S$. equi has been observed in the field, vaccines prepared by conventional procedures have proved to be relatively ineffective (Srivastava \& Barnum, 1981, 1983, 1985; Timoney \& Eggers, 1985; Woolcock, 1974; Jorm, 1990). Our aim is to produce anti-idiotypic antibodies which resemble the protective antigen(s) of $S$. equi and to evaluate their use as potential vaccines. To this end our strategy included the production of protective monoclonal antibodies (mAbs) against $S$. equi (Ab1) followed by the production of anti-idiotypic antibodies (Ab2) using these protective mAbs against $S$. equi (Abl) as immunogens. 
In this study, the ability of a preparation of partially purified $\mathrm{M}$-like protein to protect mice against a challenge with a lethal dose of $S$. equi was evaluated. Subsequently, mAbs raised against a preparation of M-like protein were assessed for their ability to protect mice against challenge with $S$. equi by means of a passive transfer assay which was developed during the course of this investigation.

\section{Methods}

S. equi isolate, growth of bacteria and determination of cell numbers in cultures of $S$. equi. A vaccine isolate of $S$. equi, 572F (CSL), was used throughout this study. The isolate was obtained from a submaxillary lymph node of a horse suffering from strangles. $S$. equi was grown in 'strangles' medium, prepared according to the CSL code of manufacture and containing $\left(\mathrm{g}^{-1}\right)$ : Neopeptone (Difco), 10; New Zealand Amine B (Sheffield Products, New York, USA), 10; yeast extract (Difco), 20; glucose (AnalaR), 30; $\mathrm{NaH}_{2} \mathrm{PO}_{4} .2 \mathrm{H}_{2} \mathrm{O}, 4 \cdot 5 ; \mathrm{Na}_{2} \mathrm{CO}_{3}$, 2.5 ; and phenol red indicator. After heating the medium to about $50^{\circ} \mathrm{C}$ to dissolve the components, the $\mathrm{pH}$ was adjusted to 7.6 with $1 \mathrm{M}-\mathrm{NaOH}$. Lyophilized stocks of the above isolate were reconstituted and used to inoculate pre-cultures. Pre-cultures $(50-100 \mathrm{ml})$ of $S$. equi grown at $37{ }^{\circ} \mathrm{C}$ overnight in $50 \%(\mathrm{v} / \mathrm{v})$ 'strangles' medium and $50 \%(\mathrm{v} / \mathrm{v})$ veal infusion (CSL) were used as inocula $(10 \%, \mathrm{w} / \mathrm{v})$ for large $(500 \mathrm{ml}-2 \mathrm{l})$ cultures which were grown at $37^{\circ} \mathrm{C}$ for $4-6 \mathrm{~h}$ in 'strangles' medium.

To determine the number of cells in a test culture, the $\mathrm{OD}_{640}$ was measured after $4-6 \mathrm{~h}$ growth and the number of cells $\mathrm{ml}^{-1}$ was estimated from a standard curve previously constructed by plotting the $\mathrm{OD}_{640}$ of samples of a culture taken at half-hourly intervals versus the number of viable cells in the culture at those time points. Viability was determined by plating out serial dilutions of the culture onto horseblood agar plates (CSL) and counting the number of colonies following incubation at $37^{\circ} \mathrm{C}$ for $24 \mathrm{~h}$. Values obtained from the standard curve were in good agreement with the assessed viability count.

Preparation and partial purification of hot-acid-extracted M-like protein. The procedure used was essentially that described by Woolcock (1974). S. equi cells, washed at least three times with $0.15 \mathrm{M}-\mathrm{NaCl}$, were resuspended in a minimal volume of the same solution. The $\mathrm{pH}$ of the suspension was brought down to 2.4 with $1 \mathrm{M}-\mathrm{HCl}$ and the suspension was extracted at $95^{\circ} \mathrm{C}$ for $15 \mathrm{~min}$. Cells and cell debris were sedimented and removed by centrifugation at $1000 \mathrm{~g}$ for $5 \mathrm{~min}$. Protease inhibitors [PMSF (Sigma), final concentration $1 \mathrm{mM}$; leupeptin (Sigma), final concentration $1 \mu \mathrm{g} \mathrm{ml}^{-1}$; and pepstatin (Sigma), final concentration $3 \mu \mathrm{g} \mathrm{ml}^{-1}$ ] were added to filtered (Whatman fast) extract. The extract was neutralized with $1 \mathrm{M}-\mathrm{NaOH}$.

The extract was then concentrated by salt fractionation with ammonium sulphate at $60 \%$ saturation. A precipitate was first obtained at $30 \%$ saturation and removed by centrifugation; the supernatant fraction was then made up to $60 \%$ salt saturation. Following solubilization and dialysis against $0.05 \mathrm{M}$-sodium acetate buffer (pH 4.5), the harvested material was loaded onto a carboxymethylcellulose (CM-cellulose) (Whatman) column. The column was washed with the same buffer and the $\mathrm{M}$-like protein was eluted with $0.02 \mathrm{M}-\mathrm{HCl}$. Peak fractions were pooled, the salt concentration adjusted to $0.15 \mathrm{M}-\mathrm{NaCl}$ and the $\mathrm{pH}$ adjusted to 7.0 with $1 \mathrm{M}-\mathrm{NaOH}$. Protein concentration was determined by the Lowry protein assay.

SDS-PAGE and Western immunoblotting. Preparations of M-like protein were analysed by gel electrophoresis on $12.5 \%$ SDS-polyacrylamide slab gels (Bio-Rad apparatus). Electrophoresis was carried out at room temperature at a constant current of $20 \mathrm{~mA}$ for about $3 \mathrm{~h}$.
Proteins were visualized with silver stain $(20 \mu \mathrm{g}$ protein per lane) or after Western immunoblotting ( $75 \mu \mathrm{g}$ protein per lane). For immunoblotting, electrophoresed proteins were transferred to nitrocellulose filters at $100 \mathrm{~V}$ for $1 \mathrm{~h}$ at $4{ }^{\circ} \mathrm{C}$ in a Bio-Rad immunoblot apparatus. The filters were blocked overnight at $37{ }^{\circ} \mathrm{C}$ with blocking buffer $[2 \%(w / v)$ BSA and $0.1 \%$ Tween-20 in PBS (10 mM-sodium phosphate, $0.15 \mathrm{M}$ $\mathrm{NaCl}, \mathrm{pH} 7 \cdot 4)]$. Horse serum or mouse ascites diluted $1: 150$ in blocking buffer were incubated with the filters for $1 \mathrm{~h}$ at $37^{\circ} \mathrm{C}$. The filters were then incubated for $1 \mathrm{~h}$ at $37^{\circ} \mathrm{C}$ either with goat anti-horse IgG (heavy and light chains) immunoglobulins conjugated to horseradish peroxidase (HRP) (KPL) at a dilution of $1: 1000$ in blocking buffer, or with goat anti-mouse IgG, IgA and IgM (heavy and light chains) immunoglobulins conjugated to HRP, at the same dilution. The reaction was detected by the addition of 3-chloro-l-naphthol ( $3 \mathrm{mg} \mathrm{ml}^{-1}$ in methanol) and $\mathrm{H}_{2} \mathrm{O}_{2}[12 \mu \mathrm{l}(30 \%, \mathrm{w} / \mathrm{v})$ in $20 \mathrm{ml}$ PBS $]$

Horse serum antibodies and passive haemagglutination. Horse serum antibodies were obtained from three horses convalescing from strangles. Blood was collected from horses 1 and 2 early in convalescence following the worst of the clinical manifestations of the disease. These horses had contracted strangles during a natural outbreak of the disease. Horse 3 was experimentally infected with $7 \times 10^{9}$ c.f.u. S. equi strain $572 \mathrm{~F}$ on each of two occasions with a 9 month interval between infections. Blood was collected 7 weeks after the primary infection and 4 weeks after the secondary infection. Horses 1 and 2 had previously been vaccinated twice at a 5 year interval with an acellular strangles vaccine [hot-acid extract (HAE) of $S$. equi isolate $572 \mathrm{~F}$ cell walls adsorbed onto aluminium hydroxide adjuvant (CSL)], whereas horse 3 had not been vaccinated and had had no known previous contact with the bacterium

Anti-S. equi antibodies were detected by passive haemagglutination. A packed cell suspension of fresh, normal sheep red blood cells was fixed with pyruvic aldehyde $[7 \cdot 4 \%(\mathrm{v} / \mathrm{v})$ in PBS, $\mathrm{pH} 7 \cdot 2]$ in a ratio of $1: 6$ by gentle stirring for $24 \mathrm{~h}$ at $4{ }^{\circ} \mathrm{C}$. The cells were centrifuged $(2000 \mathrm{~g}$, $10 \mathrm{~min}$ ), washed three times in PBS and incubated with an equal volume of tannic acid $(4 \%, \mathrm{w} / \mathrm{v})$ at room temperature for $10 \mathrm{~min}$. The tanned red blood cells were washed again as above. To sensitize them, the tanned red blood cells were incubated at room temperature for $10 \mathrm{~min}$ with 4 vols partially purified M-like protein preparation ( $3 \%$, $w / v)$, centrifuged, washed with normal rabbit serum $[0.5 \%(v / v)$ in PBS] and finally resuspended in an equal volume of normal rabbit serum.

Passive haemagglutination was carried out on enzyme immunoassay (EIA) plates (96 round-bottomed wells per plate, Dynatech); test sera diluted with normal rabbit sera $[1 \%(\mathrm{v} / \mathrm{v})$ in PBS] were added at serial doubling dilutions to the plates $(100 \mu \mathrm{l}$ per well). Sensitized red blood cells $(10 \mu \mathrm{l})$ were added and the plates were incubated at room temperature for $3 \mathrm{~h}$. The positive control consisted of horse serum of a known high antibody-titre to $S$. equi and the negative control serum was obtained from a horse with no known previous contact with $S$. equi at the time of blood collection.

Immunization of mice for mAb production. Two doses of $50 \mu \mathrm{g}$ of a partially purified M-like protein preparation in PBS, emulsified with equal volumes of either Freund's complete adjuvant (FCA) or Freund's incomplete adjuvant (FIA) were given intraperitoneally (i.p.) 2 weeks apart to raise anti-M-like protein antibodies in 8-12-week-old BALB/c mice. Mice were eye bled $10 \mathrm{~d}$ after secondary immunization. Four days before cell fusion, mice were given an intravenous injection of $50 \mu \mathrm{g} \mathrm{M}$-like protein in PBS.

Fusion of mouse spleen cells with mouse myeloma cells. Spleen cells from those mice with the highest serum titres of anti-M-like protein antibody were fused with Sp $2 / 0$ or NS- 1 myeloma cells (Stahli $e t$ al., 1980). The ratio of spleen cells to myeloma cells was $5: 1$. After the addition of $0.8 \mathrm{ml} 50 \%$ (w/v) PEG (gas chromatography grade, Merck) 
to the combined spleen/myeloma cell pellet, the fusion mixture was made up to $300 \mathrm{ml}$ in RPMI-1640 medium (CSL) containing $100 \mu \mathrm{M}$ hypoxanthine, $0.4 \mu \mathrm{M}$-aminopterin and $16 \mu \mathrm{M}$-thymidine (HAT), and $1 \mathrm{ml}$ was dispensed into each well of twelve 24-well plates. Hybridomas were screened for the production of M-like protein antibodies by EIA (see below) when they reached $30-40 \%$ confluence. Antibody-positive hybridoma supernatant fluids were further characterized by Western immunoblotting. The hybridomas were cloned at least twice by limiting dilution at concentrations of 2 cells per well, 1 cell per well and 0.5 cell per well.

Production of ascites. At least $5 \times 10^{6}$ hybridoma cells in $0.5 \mathrm{ml}$ RPMI-1640 medium were injected (i.p.) into 8-12-week-old BALB/c mice which had been primed with $0.5 \mathrm{ml}$ Pristane [2,6,10,14-tetramethyl pentadecane (Aldrich)] 2-10 d earlier (Galfre \& Milstein, 1981).

Immunoglobulin purification, concentration and isotyping. Immunoglobulins were purified from mouse sera, ascites fluid or hybridoma supernatant fluids on a Protein A-Sepharose CL-4B affinity column (Ey et al., 1978). The bound fractions were eluted and concentrated by ultrafiltration on an XM-100 membrane (Amicon).

Immunoglobulins from horse sera and IgM from mouse ascites fluid were purified by treatment with ammonium sulphate at $45 \%$ saturation. Difficulties were encountered with the purification of mouse IgM immunoglobulins in that they became partially insoluble after salt fractionation. Mouse immunoglobulin classes and isotypes were determined using an EIA kit (CSL) with mouse IgM, IgG I, IgG2a and $\operatorname{lgG} 2 \mathrm{~b}$ (Miles) as standards.

$m A b$ conjugation to $H R P$. In order to determine the epitope specificity of mAbs IDI0 and 2A6, HRP-conjugates of these mAbs were prepared. To $5 \mathrm{mg} \mathrm{HRP}$ (type VI, Sigma) dissolved in $1 \mathrm{ml}$ freshly prepared $0.3 \mathrm{M}-\mathrm{NaHCO}_{3}, 25 \mu 10.32 \%$ paraformaldehyde was added and the solution was stirred at room temperature for $30 \mathrm{~min}$. $\mathrm{NaIO}_{4}$ $(1 \mathrm{ml}, 0.04 \mathrm{M})$ was added and the solution was again stirred at room temperature for $30 \mathrm{~min}$. Ethylene glycol $(1 \mathrm{ml}, 0.16 \mathrm{M})$ was then added and the solution stirred at room temperature for $1 \mathrm{~h}$ after which it was dialysed against 1 litre $0.01 \mathrm{M}-\mathrm{Na}_{2} \mathrm{CO}_{3}$ (pH 9.5) overnight at $4{ }^{\circ} \mathrm{C}$. About $10 \mathrm{mg} \mathrm{IgG}$ in $1 \mathrm{ml}$ sodium carbonate buffer was added and the mixture incubated for $2 \mathrm{~h}$ at room temperature after which time $5 \mathrm{mg}$ $\mathrm{NaBH}_{4}$ was added and the mixture incubated for $2 \mathrm{~h}$ at $4{ }^{\circ} \mathrm{C}$. The HRP-IgG conjugate was finally dialysed against PBS overnight at $4{ }^{\circ} \mathrm{C}$.

Enzyme immunoassays (EIA). Anti-M-like protein antibodies in mouse sera and hybridoma supernatant fluids were determined by EIA. Plates were coated with $2 \mu \mathrm{g}$ per well of a preparation of partially purified $\mathrm{M}$-like protein in $0.2 \mathrm{M}$-sodium bicarbonate/sodium carbonate buffer ( $\mathrm{pH} \mathrm{9.6),} \mathrm{incubated} \mathrm{for} 3 \mathrm{~h}$ at $37^{\circ} \mathrm{C}$ and blocked with $0.1 \%$ casein and $2 \%(\mathrm{w} / \mathrm{v}) \mathrm{BSA}$ in PBS (blocking buffer) for $1 \mathrm{~h}$ at $37^{\circ} \mathrm{C}$. The plates were washed three times in $0.2 \%$ Tween-20 in PBS. Undiluted hybridoma supernatant fluid ( $100 \mu \mathrm{l}$ per well) or serial twofold dilutions of test sera in blocking buffer $(100 \mu \mathrm{l}$ per well) were added. The plates were incubated for $1.5 \mathrm{~h}$ at $37^{\circ} \mathrm{C}$ then washed as above. Anti-mouse IgG, IgM and $\operatorname{lgA}$ immunoglobulins conjugated to HRP $(100 \mu \mathrm{l}$ per well) were added at a dilution of $1: 2000$ in blocking buffer. The plates were again incubated for $1.5 \mathrm{~h}$ at $37^{\circ} \mathrm{C}$ and then washed. Equal volumes of 2,2'-azino-di(3-ethylbenzthiazoline-6-sulphonate) (ABTS; $\mathrm{KPL}$ ) and $\mathrm{H}_{2} \mathrm{O}_{2}$ substrate (KPL) were thoroughly mixed and $100 \mu \mathrm{l}$ immediately dispensed into each well. Plates were incubated for $10 \mathrm{~min}$ at $20^{\circ} \mathrm{C}$ and $A_{405}$ recorded using a Titertek Multiskan MC (Flow Laboratories). Antibody titres were expressed as the reciprocals of the end-point dilutions. A negative control consisting of normal mouse serum pooled from a group of ten mice was included on each plate. For any given test serum, the end-point titre was taken as the highest dilution at which an $A_{405}$ reading of at least twice that of the control undiluted normal mouse serum was obtained.
The epitope specificity of mAbs directed against the M-like protein preparation was determined by a competitive EIA. Serially diluted ascites fluid containing mAb $1 D 10$ or $2 \mathrm{~A} 6$ was added to plates coated with partially purified $\mathrm{M}$-like protein $(2 \mu \mathrm{g}$ per well) which were then incubated for $1.5 \mathrm{~h}$ at $37^{\circ} \mathrm{C}$. HRP-conjugated $2 \mathrm{~A} 6$ was added at a dilution of $1: 1000$ to wells pre-incubated with 1D10. HRP-conjugated $1 \mathrm{D} 10$ was added at a dilution of $1: 100$ to wells already incubated with 2A6. The plates were incubated for $1.5 \mathrm{~h}$ at $37^{\circ} \mathrm{C}$, in both instances. The dilutions of conjugated antibodies used had previously been determined by EIA against the M-like protein. The plates were developed using the procedure described above.

Active immunization - challenge assays. Groups of 10 Swiss mice were immunized (i.p.) 2 weeks apart with 50 or $100 \mu \mathrm{g}$ of either an HAE of $S$. equi or a partially purified pteparation of M-like protein (in PBS) emulsified with an equal volume of FCA or FIA. On day 21, blood was collected from each mouse to determine anti-M-like protein serum antibody titres after which each mouse was challenged (i.p.) with $2 \times 10^{6}$ or $5 \times 10^{6}$ viable $S$. equi cells in $0.2 \mathrm{ml}$ PBS.

A control group of 10 non-immunized mice was also challenged at the same time. The numbers of mice that died and the times at which they died were recorded over a period of $10 \mathrm{~d}$ post-challenge.

Passive antibody transfer assay. Immunoglobulins fractionated from horse serum (30-40 mg total protein per mouse) or mouse ascites fluid (0.5-4 mg IgG or IgM per mouse) were injected (i.p.) into Swiss mice on days 0,1 and 2 . Groups of 10 mice were used to assay each antibody. Two to three hours after the antibody injection on day 0 , each mouse was challenged (i.p.) with a lethal dose of viable $S$. equi cells $\left(2 \times 10^{6}\right.$ $3 \times 10^{6}$ cells per mouse). The numbers of mice surviving the challenge were recorded over $4 \mathrm{~d}$ post-challenge. Immune responses raised against the injected allogeneic or xenogeneic antibodies could interfere with the interpretation of the results after this time. Control mice received immunoglobulins from the serum of a horse which had not had any known previous contact with $S$. equi, or from ascites containing $\mathrm{mAbs}$ with specificity for a human immunoglobulin epitope. In all experiments at least $80 \%$ of the control mice died within $4 \mathrm{~d}$ postchallenge.

The ability of an antibody to protect mice was expressed either as the percentage protection or as the cumulative mortality index (CMI) defined as cumulative mortality in test group/cumulative mortality in control group. Thus, a CMI value of 1 indicates no protection whereas a value of 0 indicates full protection. CMI was used for ease of comparison of results in cases where passive transfer experiments were conducted on separate occasions.

\section{Results}

Hot-acid-extracted M-like protein: biochemical analysis and induction of protective immunity in mice

Partially purified M-like protein was prepared from $S$. equi by ion-exchange chromatography on a CM-cellulose column following extraction of the cells for $15 \mathrm{~min}$ at $95^{\circ} \mathrm{C}$ and pH 2.4 (Woolcock, 1974). The protein elution profile and SDS-PAGE polypeptide profile are shown in Fig. 1. The SDS-PAGE polypeptide profile revealed the heterogeneous nature of the preparation, with the presence of an intensely stained band of approximately $55 \mathrm{kDa}$ and several other prominent bands between 10 and $35 \mathrm{kDa}$. Numerous weakly stained polypeptide bands were also apparent. The protein compositions of $\mathrm{M}$-like protein preparations from different batches of 


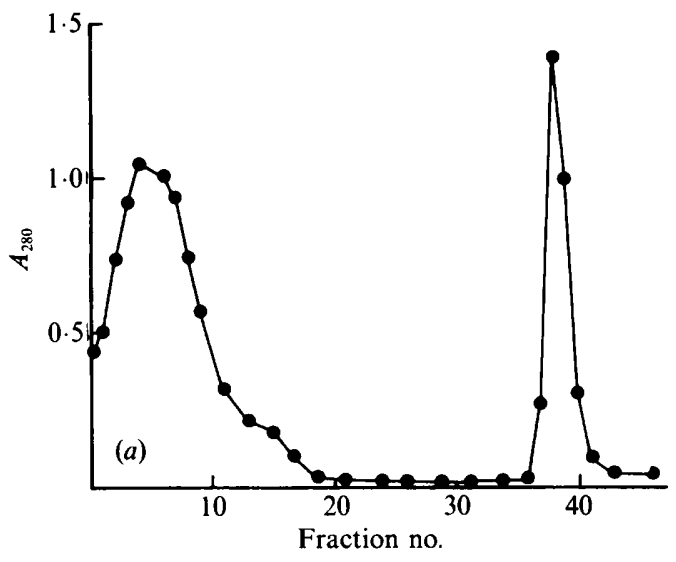

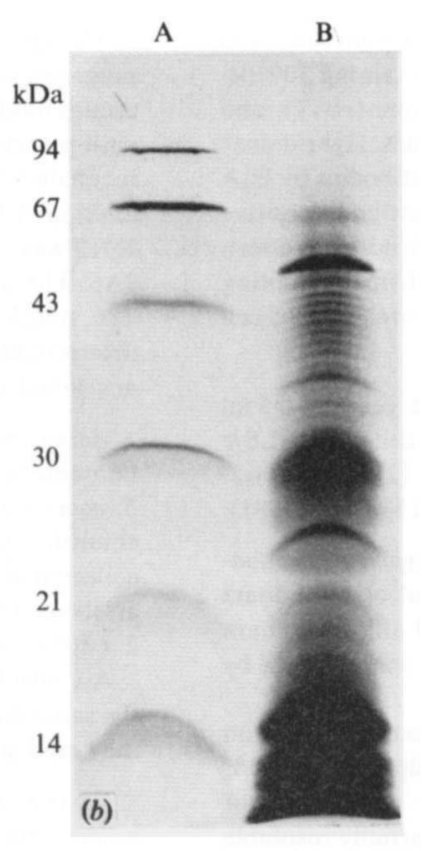

Fig. 1. Hot-acid-extracted M-like protein: elution profile following ionic exchange chromatography on a CM-cellulose column and SDSPAGE polypeptide profile of partially purified material. (a) Partially purified $\mathbf{M}$-like protein was prepared from an HAE of $S$. equi by ion-exchange chromatography on a CM-cellulose column equilibrated in $0.05 \mathrm{M}$-sodium acetate buffer, pH 4.5 (Woolcock, 1974). Concentrated hot-acidextracted protein $(20-30 \mathrm{mg})$ was loaded onto a $20 \mathrm{ml}$ bed volume column, $1.5 \mathrm{~cm}$ in diameter, and the column was washed with $0.05 \mathrm{M}$-sodium acetate buffer, pH4.5. M-like proteins were eluted $(3 \mathrm{ml}$ fractions) with $0.02 \mathrm{M}-\mathrm{HCl}$. (b) Samples of M-like protein $(20 \mu \mathrm{g})$ were electrophoresed on $12.5 \%$ SDS-polyacrylamide gels under reducing conditions (i.e. in the presence of $\beta$-mercaptoethanol in the sample buffer). Protein bands were visualized with silver stain. Lanes: A, molecular mass markers (Pharmacia); B, M-like protein preparation.
$S$. equi cells appeared to be very similar as visualized by SDS-PAGE and silver stain. The presence of a $55 \mathrm{kDa}$ band in a preparation of M-like protein has also been reported by Timoney \& Trachman (1985).

The preparation of M-like protein was assessed for its ability to induce protective immunity in mice against a lethal challenge with viable $S$. equi cells. Mice were immunized (i.p.) with 50 or $100 \mu \mathrm{g}$ of the HAE of the partially purified $\mathrm{M}$-like protein. The number of mice which survived subsequent challenge with a lethal dose of $S$. equi was recorded daily over a period of $10 \mathrm{~d}$ (Fig. 2). Of the mice immunized with $50 \mu \mathrm{g} \mathrm{HAE}, 60 \%$ were alive $10 \mathrm{~d}$ post-challenge with $5 \times 10^{6}$ viable $S$. equi cells. However, only $45 \%$ of those immunized with $100 \mu \mathrm{g}$ HAE survived. Partially purified M-like protein afforded considerably better protection, with $80 \%$ of the immunized mice surviving for $10 \mathrm{~d}$ post-challenge at both dose levels.

\section{Production and in vitro characterization of $m A$ As against a preparation of M-like protein}

A short-term immunization schedule consisting of two immunizations given i.p. 2 weeks apart was adopted to raise anti-M-like protein antibodies. High serum-antibody titres ranging between $1 / 51200$ and $1 / 204800$ were achieved, suggesting that the M-like protein was highly immunogenic in mice. Three cell-fusions were carried out using the mice that showed the highest antibody titres and 24 hybridomas producing anti-M-like protein antibodies were derived. Approximately $60 \%$ of these produced antibodies of the IgM isotype, while the rest produced IgG, the majority of these being of the IgG1 isotype.

Components of the M-like protein preparation which were recognized by the mAbs were identified by Western immunoblotting. The results shown in Fig. 3 are representative of all the mAbs analysed and show an apparently heterogeneous pattern of epitope recognition despite the fact that the hybridomas were cloned at least twice to ensure monoclonality. Fig. 3 also shows that there are two major recognition patterns for these mAbs, one consisting of polypeptide bands predominantly in the $25-55 \mathrm{kDa}$ range (banding pattern 1 ; lane $\mathrm{B}$ ) and including the 46 and $41 \mathrm{kDa}$ fragments of the M-like protein described by Galan \& Timoney (1987), the other including 2-3 major low molecular mass components $(7-15 \mathrm{kDa})$ as well as a $55 \mathrm{kDa}$ polypeptide band (banding pattern 2 ; lane $D$ ). A comparison of the immunoblot profile of the mAbs with that of convalescent horse serum antibodies (lane $F$ ) revealed that mAbs displaying recognition banding pattern 1 recognized several polypeptide bands with $M_{\mathrm{r}}$ values in the $20-55 \mathrm{kDa}$ range which were also recognized by horse serum antibodies.

\section{Development of an in vivo passive transfer assay for the identification of protective $m A b s$}

In order to assess the ability of the mAbs to protect against $S$. equi infection, an in vivo passive transfer assay was developed in mice using serum antibodies harvested 


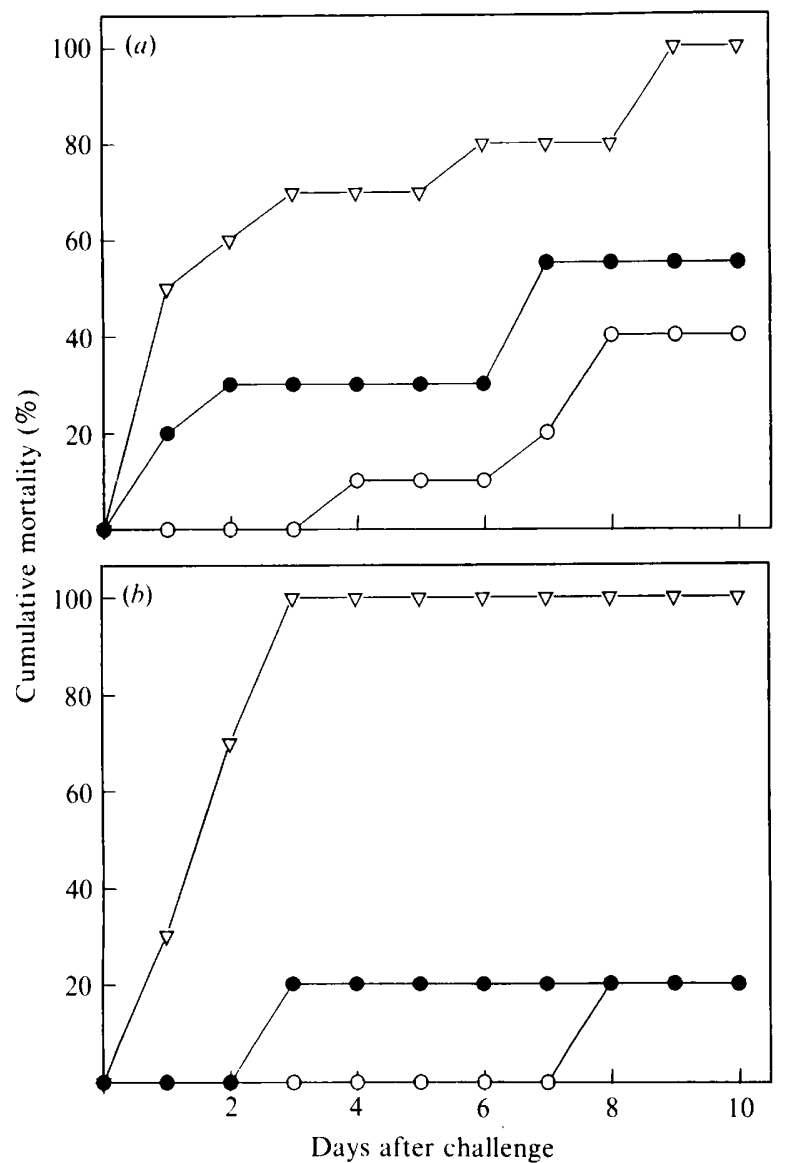

Fig. 2. Induction of protective immunity in mice by hot-acid-extracted $S$. equi antigens. Groups of 10 Swiss mice were immunized (i.p.) 2 weeks apart with 50 or $100 \mu \mathrm{g}$ of $(a)$ HAE or $(b)$ M-like protein in FCA or FIA. On day 21, each mouse was challenged (i.p.) with (a) $5 \times 10^{6}$ or $\left(\right.$ b) $2 \times 10^{6}$ c.f.u. viable $S$. equi cells in $0.2 \mathrm{ml}$ PBS. A control group of non-immunized mice was challenged at the same time. The number of mice that died and the time at which they died was recorded over a period of $10 \mathrm{~d}$ post-challenge. $\nabla$, Control mice; $O$, $50 \mu \mathrm{g} \mathrm{HAE}$ or M-like protein; $\bullet 100 \mu \mathrm{g}$ HAE or M-like protein.

from three horses convalescing from strangles. Horses 1 and 2 had been vaccinated previously and contracted strangles from a natural outbreak of the disease, whereas horse 3 had not been previously vaccinated and was experimentally infected with $S$. equi. Serum antibodies from horses 1 and 2 had a high titre $(1 / 100000)$ against M-like protein as determined by passive haemagglutination assays, while antibodies from horse 3 had a low titre (highest titre 1/3200). The results of the passive transfer assay are shown in Fig. 4; over a period of $4 \mathrm{~d}$, both high- and low-titre serum antibodies afforded good protection $(70-80 \%)$ to mice challenged with $2-3 \times 10^{6}$ c.f.u. $S$. equi cells. Control mice were given immunoglobulins from horses which were not known to have been in contact with the bacteria. A maximum of $20 \%$ of the control mice survived $4 \mathrm{~d}$ post-challenge.

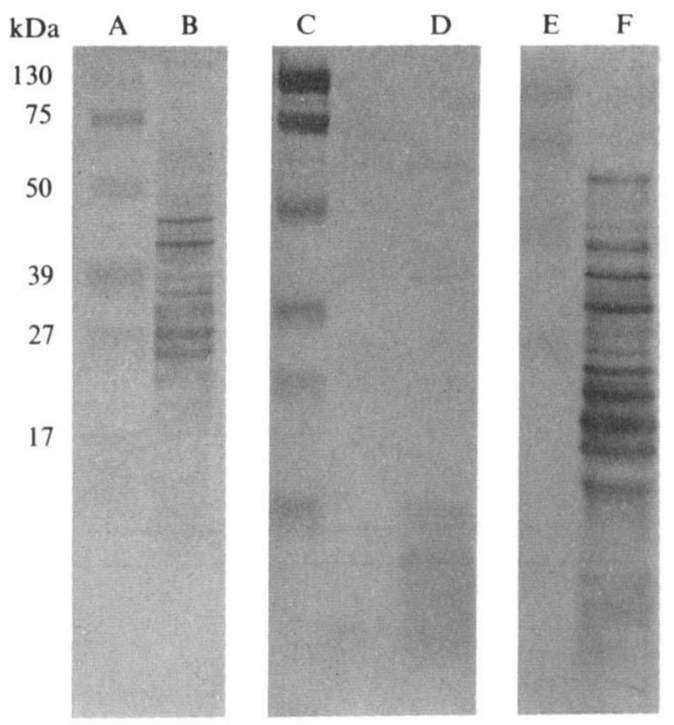

Fig. 3. Immunological reactivity of $\mathrm{M}$-like protein with mouse mAbs and horse serum antibodies. Hot-acid-extracted M-like protein $(75 \mu \mathrm{g})$ was electrophoresed on $12.5 \%$ SDS-polyacrylamide slab gels at $20 \mathrm{~mA}$ for $3 \mathrm{~h}$ at room temperature and transferred onto nitrocellulose filters at $100 \mathrm{~V}$ for $1 \mathrm{~h}$ at $4{ }^{\circ} \mathrm{C}$ in a Bio-Rad immunoblot apparatus. Pre-stained markers (10 $\mu \mathrm{l}$, Bio-Rad) were also electrophoresed alongside each sample of M-like protein, transferred onto the same piece of nitrocellulose filter and immunoblotted. The filters were blocked with $2 \%$ BSA and $0.1 \%$ Tween-20 in PBS overnight at $37{ }^{\circ} \mathrm{C}$. Mouse ascites fluids and horse serum, diluted $1: 150$ in blocking buffer, were incubated with the filters for $1 \mathrm{~h}$ at $37^{\circ} \mathrm{C}$. Goat anti-mouse $\operatorname{IgG}, \operatorname{IgA}$ and IgM (heavy and light chains) immunoglobulins conjugated to HRP and goat anti-horse IgG (heavy and light chains) immunoglobulins conjugated to HRP were added at a dilution of $1: 1000$ in blocking buffer. The reaction was detected by the addition of 3-chloro1-naphthol $\left(3 \mathrm{mg} \mathrm{m}^{-1}\right)$. Control serum obtained from a horse which had no known previous contact with $S$. equi and ascites fluids obtained from a murine cell line producing $\mathrm{mAbs}$ against human IgG showed no reaction (result not shown). Lanes: A, C, E, molecular mass markers; B, mAb $1 \mathrm{D} 10$ (banding pattern 1 ); $\mathrm{D}, \mathrm{mAb} 7 \mathrm{Cl}$ (banding pattern 2); $\mathrm{F}$, serum from a convalescing horse.

Passive protection of mice against S. equi infection by anti-M-like protein $\mathrm{mAbs}$

Eight murine $\mathrm{mAbs}$ were assessed for their in vivo ability to protect mice against challenge with $S$. equi. Four of the mAbs displayed recognition banding pattern 1 on a Western immunoblot, i.e. reactivity with polypeptide bands predominantly in the $25-55 \mathrm{kDa}$ range (Fig. 3), while the other four displayed recognition banding pattern 2 , i.e. reactivity with the $55 \mathrm{kDa}$ polypeptide band in addition to two to three polypeptide bands with $M_{\mathrm{r}}$ values ranging between 7 and $15 \mathrm{kDa}$. The results shown in Table 1 demonstrate that the mAbs fall into three categories: those which afforded good protection (CMI, 0.14-0.25), viz. mAbs $1 \mathrm{Dl0}$ and 2A6; those which afforded some protection (CMI, 0.77), viz. mAb 


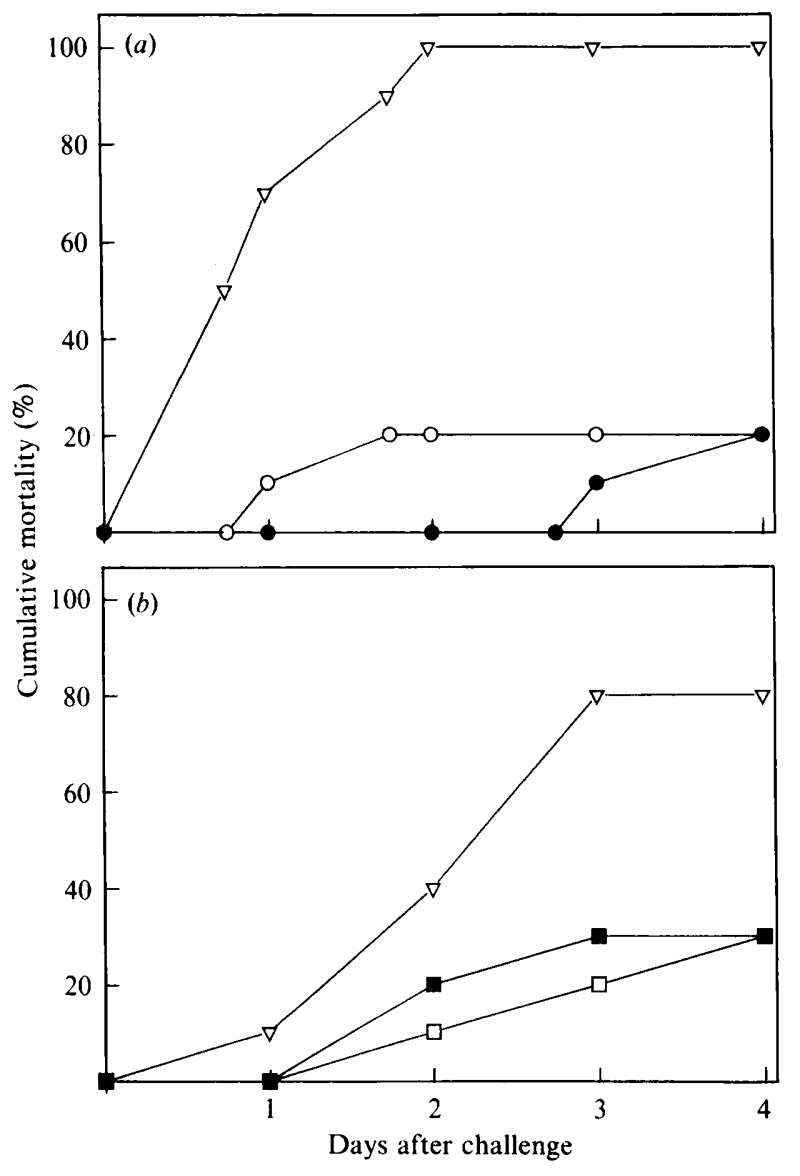

Fig. 4. Passive protection of mice by horse serum antibodies. Immunoglobulins fractionated from horse serum $(30-40 \mathrm{mg}$ total protein per mouse) were injected (i.p.) into groups of 10 Swiss mice on days 0,1 and 2. Two or three hours after the antibody injection on day 0 , each mouse was challenged with a lethal dose of viable $S$. equi cells [(a) $3 \times 10^{6}$ and $(b) 2 \times 10^{6}$ c.f.u.]. The number of mice surviving the challenge was recorded over $4 \mathrm{~d}$ post-challenge. Control mice $(\nabla)$ received immunoglobulins from a horse which had not had any known previous contact with $S$. equi (passive haemagglutination titre varying between $1 / 2$ and 1/128). (a) Results obtained with serum from horses 1 $(O)$ and $2(\bullet)$, which had previously been vaccinated and were naturally infected with $S$. equi (passive haemagglutination titre: 1/100000). (b) Results obtained with serum from horse 3, which had not been vaccinated previously and was experimentally infected with $S$. equi on each of two occasions. $\square$, Serum harvested after the primary infection; $\square$, serum harvested after the secondary infection (passive haemagglutination titres after the primary and secondary infections were $1 / 3200$ and $1 / 512$, respectively).

$10 \mathrm{C} 5$; and those which afforded no protection (CMI, 0.86-1.0), viz. mAbs 2D3, 3D4, 7C1, 7D1 and 10D3.

It should be noted that the two $\mathrm{mAbs}$ which gave the best protection, $1 \mathrm{D} 10$ and $2 \mathrm{~A} 6$, also displayed the same recognition banding pattern on a Western immunoblot, viz. recognition banding pattern 1 . In contrast, the four mAbs which displayed recognition banding pattern 2 , namely $2 \mathrm{D} 3,7 \mathrm{Cl}, 7 \mathrm{D} 1$ and $10 \mathrm{C} 5$, afforded little or no
Table 1. Some characteristics and properties of the anti-M-like protein $\mathrm{mAbs}$

\begin{tabular}{lccc}
\hline \hline mAb & $\begin{array}{c}\text { Western } \\
\text { light chain }\end{array}$ & $\begin{array}{c}\text { Passive } \\
\text { immunoblot } \\
\text { pattern }\end{array}$ & $\begin{array}{c}\text { protection } \\
\text { (CMI) }\end{array}$ \\
\hline 1D10 & IgG1 $\kappa$ & 1 & $0 \cdot 25$ \\
2A6 & IgG1 $\kappa$ & 1 & $0 \cdot 14$ \\
2D3 & IgM $\kappa$ & 2 & $0 \cdot 89$ \\
3D4 & IgM $\kappa$ & 1 & $1 \cdot 0$ \\
7Cl & IgM $\kappa$ & 2 & $1 \cdot 0$ \\
7D1 & IgG1 $\kappa$ & 2 & 0.86 \\
10C5 & ND $\kappa$ & 2 & 0.77 \\
10D3 & IgM $\kappa$ & 1 & 0.93 \\
\hline \hline
\end{tabular}

ND, Not determined.

protection. The isotype of the antibody may be important in conferring protection because, even though mAbs 1D10, 2A6, 3D4 and 10D3 all displayed recognition banding pattern 1 on a Western immunoblot, only 1D10 and $2 \mathrm{~A} 6$ were protective; $1 \mathrm{D} 10$ and $2 \mathrm{~A} 6$ were $\mathrm{IgG} 1$ antibodies whereas 3D4 and 10D3 were IgM antibodies (Table 1).

Establishment of a dose-response (protection) curve for mAbs $1 D 10$ and $2 A 6$

In order to achieve the maximum level of protection with the minimum amount of antibody, the two protective mAbs, $1 \mathrm{D} 10$ and 2A6, were assayed individually and together at various concentrations in an in vivo passive transfer assay. Dose-response curves were established using antibody concentrations of $0.5,1 \cdot 0,2 \cdot 0$ and $4.0 \mathrm{mg}$ per mouse (Fig. 5). The highest level of passive protection was achieved using $1 \mathrm{mg}$ of either $1 \mathrm{D} 10$ or $2 \mathrm{~A} 6$, or $0.5 \mathrm{mg} 1 \mathrm{D} 10$ and $0.5 \mathrm{mg} 2 \mathrm{~A} 6$ given together. The level of protection attained with 2.0 or $4.0 \mathrm{mg} 1 \mathrm{D} 10$ was less than that attained with 0.5 or $1.0 \mathrm{mg}$, respectively. When 1D10 and 2A6 were given together, the level of protection was greater than that achieved using $1 \mathrm{D} 10$ alone; however, it was not, in most cases, significantly different from the level achieved using $2 \mathrm{~A} 6$ alone.

mAbs $1 D 10$ and $2 A 6$ recognize different epitopes in a preparation of partially purified $M$-like protein

The possibility existed that mAbs $1 \mathrm{D} 10$ and $2 \mathrm{~A} 6$ had specificity for the same epitope on a particular protein present in a partially purified preparation of $\mathrm{M}$-like protein. A competitive EIA was developed to investigate this possibility.

Serially diluted ascites fluids containing mAbs $1 D 10$ or $2 \mathrm{~A} 6$ were added to M-like-protein-coated EIA plates. 


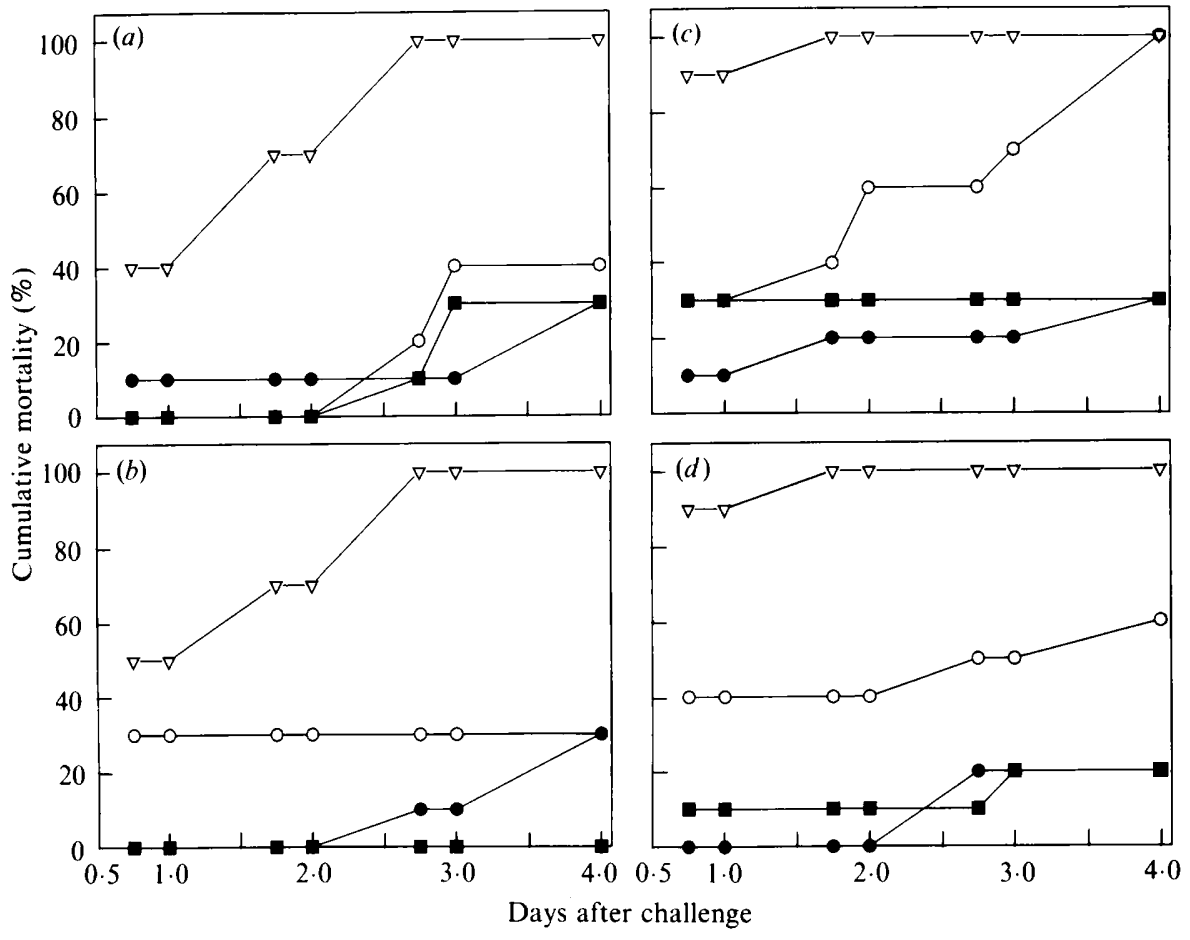

Fig. 5. Dose-response (protection) curve for $\mathrm{mAbs} 1 \mathrm{Dl} 0$ and 2A6. Mouse ascites fluids ( $0.3 \mathrm{ml}$ containing $0.5-4 \mathrm{mg}$ immunoglobulins per mouse) were injected (i.p.) into groups of 10 Swiss mice on days 0,1 and 2. Details of the experiment were the same as for Fig. 4 except that control mice $(\nabla)$ received ascites fluid containing mAbs with specificity for a human immunoglobulin epitope. Ascites fluids were used throughout the experiment. Ascites fluids containing mAbs $1 \mathrm{D} 10$ or $2 \mathrm{~A} 6$ obtained from the same pools of ascites fluids were used throughout the experiment. Ascites fluids containing $1 D 10$ had a titre of $1 / 512000$ as assessed by EIA against M-like protein and ascites fluids containing $2 \mathrm{~A} 6$ had a titre of $1 / 1024000$. The challenge dose of $S$. equi per mouse was $(a, b) \quad 3 \times 10^{6}$ and $(c, d)$ $2 \times 10^{6}$ c.f.u. $O$, mAb 1D10: (a) $0.5 \mathrm{mg}$, (b) $1.0 \mathrm{mg}$, (c) $2.0 \mathrm{mg},(d) 4.0 \mathrm{mg}$. $\bullet, \mathrm{mAb}$ 2A6: (a) $0.5 \mathrm{mg},(b) 1.0 \mathrm{mg}$, (c) $2.0 \mathrm{mg}$, (d) $4.0 \mathrm{mg}$. $\mathrm{mAbs} 1 \mathrm{D} 10$ and 2A6: (a) $0.5 \mathrm{mg}$, (b) $1.0 \mathrm{mg},(c) 2.0 \mathrm{mg},(d) 4.0 \mathrm{mg}$. (Each total dose shown was made up of equal proportions of $\mathrm{mAbs} 1 \mathrm{D} 10$ and 2A6.)
HRP-conjugated $2 \mathrm{~A} 6$ was then added at a fixed dilution to wells which had already been incubated with 1D10, while HRP-conjugated 1D10 was added to wells which had been incubated with 2A6. The results (Fig. 6)

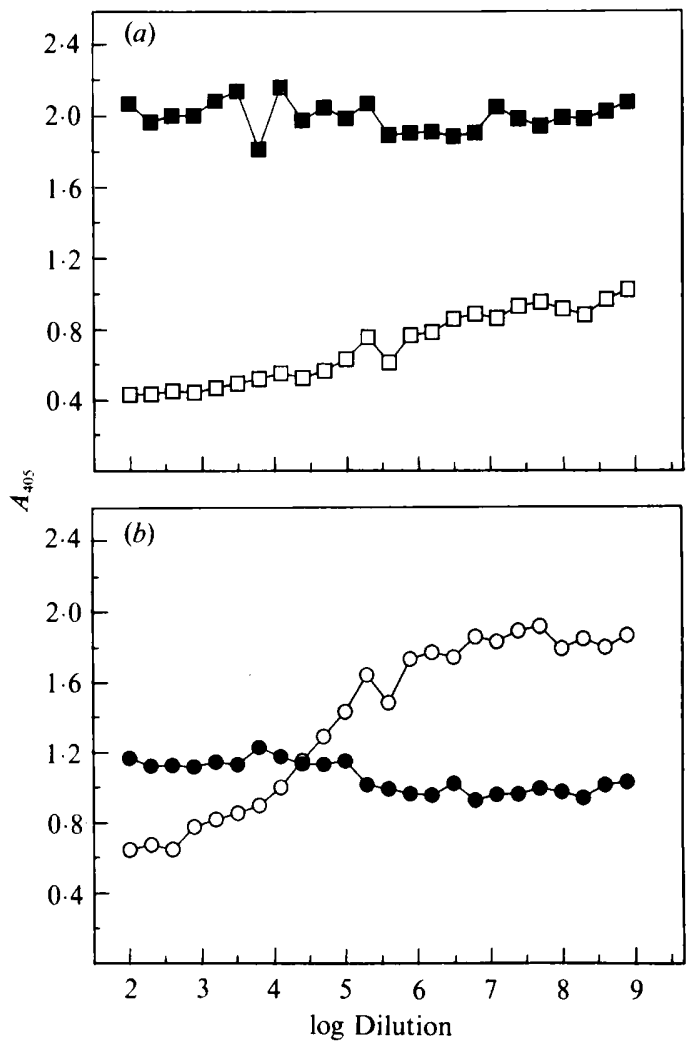

showed that the $A_{405}$ values obtained for both mAbs were fairly constant, varying between 1.80 and 2.04 when HRP-conjugated 2A6 was added to wells pre-incubated with serial dilutions of $1 \mathrm{D} 10$ (Fig. $6 a$ ) and between 0.92 and 1.20 when HRP-conjugated 1D10 was added to wells pre-incubated with serial dilutions of $2 \mathrm{~A} 6$ (Fig. $6 b$ ). The results suggested that, at the concentrations tested, $1 \mathrm{D} 10$ and 2A6 did not alter the extent of binding of conjugated $2 \mathrm{~A} 6$ and $1 \mathrm{D} 10$, respectively, to M-like protein. This implied that the epitopes recognized by $1 \mathrm{D} 10$ and $2 \mathrm{~A} 6$ were dissimilar and that at least two mouse-protective epitopes were present in a preparation of $\mathrm{M}$-like protein. As expected, the amount of HRP-conjugated 1D10 (or 2A6) which bound to M-like protein increased as the amount of unconjugated 1D10 (or 2A6) was decreased. The observed increase in $A_{405}$ was greater for the $2 \mathrm{~A} 6$ conjugate than for the $1 \mathrm{D} 10$ conjugate. This may be explained by the fact that the $2 \mathrm{~A} 6$ conjugate had a titre of 1/2050 against M-like protein as assessed by EIA whereas the $1 \mathrm{D} 10$ conjugate had a titre of $1 / 256$.

Fig. 6. Epitope specificity of $\mathrm{mAbs} \mathrm{ID} 10$ and $2 \mathrm{~A} 6$. A competitive EIA was developed to determine the epitope specificity of mAbs 1D10 and 2A6. Serially diluted ascites fluids containing $1 \mathrm{D} 10$ or $2 \mathrm{~A} 6$ were added to M-like-protein-coated plates $(2 \mu \mathrm{g}$ per well) which were then incubated for $1.5 \mathrm{~h}$ at $37^{\circ} \mathrm{C}$. HRP-conjugated $2 \mathrm{A6}$ was added at a dilution of $1: 1000$ to wells already incubated with 1D10 and HRPconjugated 1D10 was added at a dilution of 1:100 to wells already incubated with $2 \mathrm{~A} 6$; the plates were incubated for $1.5 \mathrm{~h}$ at $37^{\circ} \mathrm{C}$. ABTS substrate was added and $A_{405}$ recorded as described in Methods. (a) $\square$, 1D10 with HRP-conjugated 2A6; $\square$, 1D10 with HRPconjugated ID10. (b) $\bullet, 2 \mathrm{~A} 6$ with HRP-conjugated $1 \mathrm{D} 10 ; 0,2 \mathrm{~A} 6$ with HRP-conjugated $2 \mathrm{A6}$. 


\section{Discussion}

In this study a partially purified preparation of M-like protein, obtained by extracting $S$. equi cells in hot acid (Woolcock, 1974) was shown to afford a high level of protection $(80 \%)$ to immunized mice that were subsequently challenged with a lethal dose of $S$. equi. This is in agreement with the findings of Woolcock (1974) and Timoney \& Galan (1985). M-protein is believed to be the major virulence factor of group A streptococci (Lancefield, 1928; Beachey, 1985), rendering the streptococcus resistant to non-immune phagocytosis (Bisno, 1979; Peterson et al., 1979). M-protein isolated from group A streptococci by hot-acid extraction (Lancefield, 1928), sonication (Besdine \& Pine, 1968), alkaline extraction (Fox \& Wittner, 1969), pepsin digestion (Cunningham \& Beachey, 1974), streptococcal phage lysin (Fischetti et al., 1974), guanidine. $\mathrm{HCl}$ (Russell \& Facklam, 1975) and non-ionic detergents (Fischetti et al., 1976) has been shown to be heterogeneous. The hot-acid-extracted M-like protein of group C $S$. equi, which was partially purified in this study, was found to be a heterogeneous preparation, presumably containing $\mathbf{M}$-protein and its smaller breakdown fragments in addition to other protein. Some of these proteins/polypeptides were shown to be mouse-protective. It is interesting that a higher level of protection $(60 \%)$ was consistently obtained with $50 \mu \mathrm{g}$ HAE than with $100 \mu \mathrm{g}$ of the same preparation $(45 \%)$.

In addition $\mathrm{mAbs}$ raised against a partially purified preparation of M-like protein isolated from $S$. equi can afford a high level of passive protection to mice challenged with a lethal dose of the bacteria. The passive transfer assay used in this study was adapted from methods described by Woolcock (1974), Erickson \& Norcross (1975), Mathews \& Roehrig (1982) and Srivastava \& Barnum (1983). These authors reported that a single dose of polyclonal antibody was satisfactory for protection. In our experience, effective protection was not achieved with a single dose of either murine monoclonal or equine polyclonal antibody. At least $1.5 \mathrm{mg}$ of antibodies per mouse, administered over $3 \mathrm{~d}$, was deemed necessary for protection from the large challenge dose of bacteria used in the experiments reported here. Both murine monoclonal and equine polyclonal antibodies were equally effective in our assay. Despite the fact that each hybridoma had been cloned at least twice to ensure monoclonality, all the mAbs recognized multiple polypeptide bands on Western immunoblots. This indicates the presence of breakdown products of a single protein in the antigen preparation or cross-reacting epitopes on different proteins/polypeptides, or both. It is interesting to note that the two protective mAbs, $1 \mathrm{D} 10$ and $2 \mathrm{~A} 6$, displayed the same recognition banding pattern, i.e. pattern 1 , on a Western immunoblot. In addition, several of the proteins/ polypeptides recognized by these $\mathrm{mAbs}$ were also recognized by mouse-protective horse antibodies. Determination of epitope specificity of these mAbs revealed the existence of two mouse-protective epitopes in the $\mathrm{M}$-like protein preparation.

In addition to displaying the same immunoblot banding pattern, mAbs $1 \mathrm{D} 10$ and $2 \mathrm{~A} 6$ were both of the IgG isotype. mAbs 3D4 and 10D3, on the other hand, were both of the IgM isotype and non-protective, despite the fact that they appeared identical to $1 \mathrm{D} 10$ and 2A6 in their reaction against $\mathrm{M}$-like protein on immunoblots (data not shown). These findings suggest that both the specificity and the isotype of the immunoglobulin in question may be important in conferring protection. The difficulties encountered in purifying the more unstable IgM from ascites fluids containing mAbs 3D4 and 10D3 and the difficulty in producing murine IgM-containing ascites with titres of the same orders of magnitude as IgG-containing ascites may also explain the observed lack of protection with 3D4 and 10D3. Even though it has been shown that the two protective mAbs $1 D 10$ and 2A6 recognized different epitopes in a preparation of M-like protein, their ability to protect mice was not necessarily synergistic. This aspect requires further investigation.

Despite the fact that not all aspects of the passive protection assay were extensively investigated, the assay has been used successfully in this study to identify protective $\mathrm{mAbs}$ directed against the $\mathbf{M}$-like protein of $S$. equi. Future work will involve the use of this assay for the identification of other immunogenic epitopes which are required for effective protection against $S$. equi infection.

This work was supported by the Generic Technology component of the Industry, Research and Development Act (1986), Australia, and by the Commonwealth Serum Laboratories, Victoria, Australia, from 1986 to 1989 . We are grateful to Mr R. Hamilton for photographing gels and Western immunoblots, and to Ms L. McDonald and Ms L. Murray for typing the manuscript.

\section{References}

Beachey, E. H. (1985). Protective immunity evoked by synthetic peptides of streptococcal $\mathbf{M}$ proteins. In Advances in Experimental Medicine and Biology, vol. 185, pp. 193-200. Edited by M. Z. Atassi \& H. L. Bachnach. New York: Plenum Press.

Besdine, R. W. \& Pine, L. (1968). Preparation and description of high molecular weight soluble surface antigens from a Group A streptococcus. Journal of Bacteriology 96, 1953-1960.

Bessen, D. \& Fischetti, V. A. (1988a). Passively acquired mucosal immunity to Group A streptococci by secretory immunoglobulin A. Journal of Experimental Medicine 167, 1945-1950. 
Bessen, D. \& Fischetti, V. A. (1988b). Influence of intranasal immunization with synthetic peptides corresponding to conserved epitopes of $\mathbf{M}$ protein on mucosal colonization by Group $\mathbf{A}$ streptococci. Infection and Immunity 56, 2555-2672.

BisNo, A. L. (1979). Alternative complement pathway activation by group A streptococci: role of $\mathrm{M}$ protein. Infection and Immunity 26, 1172-1176.

Cunningham, M. W. \& Beachey, E. H. (1974). Peptic digestion of streptococcal $\mathrm{M}$ protein. I. Effect of digestion at suboptimal $\mathrm{pH}$ upon the biological and immunochemical properties of purified $\mathbf{M}$ protein extracts. Infection and Immunity 9, 244-248.

Commonwealth Serum Laboratories (1979). CSL Veterinary Handbook. Parkville: Commonwealth Serum Laboratories.

ERICKSON, E. D. \& NorCRoss, N. L. (1975). The cell surface antigens of Streptococcus equi. Canadian Journal of Comparative Medicine 39, $110-115$.

Ey, P. L., Prowse, S. J. \& Jenkin, C. R. (1978). Isolation of pure IgG 1 , $\mathrm{IgG}_{2} \mathrm{a}$ and $\mathrm{IgG}_{2} \mathrm{~b}$ immunoglobulins from mouse serum using Protein A-Sepharose. Immunochemistry 15, 429-436.

FischetTI, V. A., Zabriskie, J. B. \& Gotschlich, E. C. (1974). Physical, chemical and biological properties of type $6 \mathrm{M}$ protein extracted with purified streptococcal phage-associated lysin. In Streptococcal Disease and the Community, p. 26. Edited by J. J. Haverkorn. Amsterdam: Excerpta Medica.

Fischetti, V. A., Gotschlich, E. C., Siviglia, G. \& Zabriskie, J. B. (1976). Streptococcal M protein extracted by non-ionic detergent. I. Properties of the antiphagocytic and type-specific molecules. Journal of Experimental Medicine 144, 32-53.

Fox, E. N. \& WITTNER, M. K. (1969). New observations on the structure and antigenicity of the $M$ proteins of the group $A$ streptococcus. Immunochemistry 6, 11-24.

Fox, E. N. (1974). M proteins of Group A streptococci. Bacteriological Reviews 38, 57-86.

Galan, J. E. \& Timoney, J. F. (1985). Mucosal nasopharyngeal immune responses of horses to protein antigens of Streptococcus equi. Infection and Immunity 47, 623-628.

Galan, J. E. \& Timoney, J. F. (1987). Molecular analysis of the $M$ protein of Streptococcus equi and cloning and expression of the $\mathbf{M}$ protein gene in Escherichia coli. Infection and Immunity 55, 3181-3187.

Galfre, G. \& Milstein, C. (1981). Preparation of monoclonal antibodies: strategies and procedures. Methods in Enzymology 73, $3-46$.

JORM, L. R. (1990). Strangles in horse studs: incidence, risk factors and effect of vaccination. Australian Veterinary Journal 67, 436-439.
LanCefield, R. C. (1928). The antigenic complex of Streptococcus hemolyticus. I. Demonstration of a type-specific substance in extracts of Streptococcus hemolyticus. Journal of Experimental Medicine 47, 91-103.

Mathews, J. H. \& Roehrig, J. T. (1982). Determination of the protective epitopes on the glycoproteins of Venezuelan equine encephalomyelitis virus by passive transfer of monoclonal antibodies. Journal of Immunology 129, 2763-2767.

Peterson, P. K., Schmeling, D., Cleary, P. P., Wilkinson, K. \& QUIE, P. G. (1979). Inhibition of alternative complement pathway opsonization by group A streptococcal $\mathbf{M}$ protein. Journal of Infectious Diseases 139, 575-585.

Phillips, G. N., Flicker, P. F., Cohen, C., Manjula, B. N. \& FisCHETTI, V. A. (1981). Streptococcal M protein: $\alpha$-helical coiledcoil structure and arrangement on the cell surface. Proceedings of the National Academy of Sciences of the United States of America 78, 4689-4693.

Russell, H. \& Facklam, R. R. (1975). Guanidine extraction of streptococcal $M$ protein. Infection and Immunity 12, 679-686.

SRIVASTAVA, S. K. \& BARNUM, D. A. (1981). The serological response of foals to vaccination against strangles. Canadian Journal of Comparative Medicine 45, 20-25.

SRivastava, S. K. \& BaRnum, D. A. (1983). Vaccination of pony foals with M-like protein of Streptococcus equi. American Journal of Veterinary Research 44, 41-45.

Srivastava, S. K. \& Barnum, D. A. (1985). Studies on the immunogenicity of Streptococcus equi vaccines in foals. Canadian Journal of Comparative Medicine 49, 351-356.

Stahli, C., Staehelin, T., Miggiano, V., Schmidt, J. \& Haring, P. (1980). High frequencies of antigen specific hybridomas: dependence on immunization parameters and prediction by spleen cell analysis. Journal of Immunological Methods 32, 297-304.

Timoney, J. F. \& Trachman, J. (1985). Immunologically reactive proteins of Streptococcus equi. Infection and Immunity 48, 29-34.

TimoneY, J. F. \& EGgers, D. (1985). Serum bactericidal responses to Streptococcus equi of horse following infection or vaccination. Equine Veterinary Journal 17, 306-310.

TimoneY, J. F. \& Galan, J. E. (1985). The protective response of the horse to an avirulent strain of Streptococcus equi. In Recent Advances in Streptococci and Streptococcal Diseases, pp. 294-295. Edited by Y. Kimura, S. Kotami, Y. Shiokawa \& N. W. Danbury. Chertsey: Reed Books.

Woolcock, J. B. (1974). Purification and antigenicity of an M-like protein of Streptococcus equi. Infection and Immunity 10, 116-122. 